\title{
FAKTOR DETERMINAN PRESTASI BELAJAR AKUNTANSI
}

\section{FACTORS OF ACCOUNTING LEARNING ACHIEVEMENT}

\author{
Oleh: \\ Bebi Ratnasari \\ Pendidikan Akuntansi Universitas Negeri Yogyakarta \\ bebiratnasari92@gmail.com
}

$\underline{\text { Sukirno }}$

Staf Pengajar Jurusan Pendidikan Akuntansi Universitas Negeri Yogyakarta

\begin{abstract}
Abstrak
Penelitian ini bertujuan untuk mengetahui pengaruh Motivasi Belajar, Persepsi Siswa tentang Kompetensi Guru, dan Lingkungan Keluarga terhadap Prestasi Belajar Akuntansi Perusahaan Dagang. Populasi dalam penelitian ini adalah siswa kelas XI Akuntansi SMK YPKK 2 Sleman Tahun Ajaran 2016/2017 yang berjumlah 115 siswa. Data dikumpulkan dengan metode angket dan metode dokumentasi. Teknik analisis data yang digunakan adalah analisis regresi. Hasil penelitian ini adalah Pengaruh Motivasi Belajar, Persepsi Siswa tentang Kompetensi Guru, dan Lingkungan Keluarga secara individu dan bersama-sama berpengaruh positif terhadap Prestasi Belajar Akuntansi Perusahaan Dagang yang ditunjukkan dengan nilai $r_{x 1 y}=0,491 ; r_{x 1 y}^{2}=0,241 ; r_{x 2 y}=0,391 ; r_{x 2 y}^{2}=0,153$; $r_{x 3 y}=0,328 ; r^{2}{ }_{x y y}=0,108 ; R_{x(1,2,3) y}=0,576 ; R_{x(1,2,3) y}^{2}=0,332$ dengan total Sumbangan Efektif yaitu $33,20 \%$.
\end{abstract}

Kata Kunci: Prestasi Belajar Akuntansi Perusahaan Dagang, Motivasi Belajar, Persepsi Siswa tentang Kompetensi Guru, Lingkungan Keluarga

\begin{abstract}
This research aims to know the effect of Learning Motivation, Teacher Competence, and Family Environment oward the Learning Achievement of Accounting Trading Company. The population of the research are 115 students of Class XI in Accounting of SMK YPKK 2 Sleman in Academic Year 2016/2017. Data were collected by questionnaire and documentation methods. The data analysis used is regression analysis. The results of the research were, there were positive effect of Learning Motivation, Teacher Competence, and Family Environment individually and together toward the Learning Achievement of Accounting Trading Company as shown $r_{x l y}=0,491 ; r_{x l y}^{2}=0,241 ; r_{x 2 y}=0,391$; $r_{x 2 y}^{2}=0,153 ; r_{x 3 y}=0,328 ; r_{x 3 y}^{2}=0,108 ; R_{x(1,2,3) y}=0,576 ; R_{x(1,2,3) y}^{2}=0,332$ and total effective contribution $33,20 \%$
\end{abstract}

Keywords: Learning Achievement of Accounting Trading Company, Learning Motivation, Teacher Competence, Family Environment

\section{PENDAHULUAN}

Menurut pasal 1 (ayat 1) Undangundang RI No. 20 Tahun 2003 tentang Sistem Pendidikan Nasional, yaitu:

Pendidikan adalah usaha sadar dan terencana untuk mewujudkan suasana belajar dan proses pembelajaran agar peserta didik secara aktif mengembangkan potensi dirinya untuk memiliki kekuatan spriritual keagamaan, pengendalian diri, kepribadian, kecerdasan, akhlak mulia, serta keterampilan yang diperlukan dirinya, masyarakat, bangsa dan Negara.

Keberhasilan seorang siswa dalam belajar dapat dilihat dari prestasi belajar siswa itu sendiri. Di dalam pendidikan, siswa dinilai keberhasilannya melalui hasil tes belajar dalam kegiatan pembelajaran yang bertujuan untuk mengetahui sejauh mana siswa tersebut menguasai materi yang 
telah disampaikan oleh guru saat proses pembelajaran. Hasil yang diharapkan adalah prestasi belajar yang optimal dan tinggi karena setiap orang menginginkan prestasi yang tinggi, baik siswa, orang tua, guru, maupun sekolah hingga masyarakat. Dalam hal ini Prestasi belajar merupakan sebagai standar kemajuan mutu pendidikan di sekolah, karena prestasi belajar merupakan indikator penting dari mutu pendidikan di sekolah. Peningkatan prestasi belajar siswa diupayakan dan dilakukan pada semua mata pelajaran, termasuk Akuntansi Perusahaan Dagang.

Prestasi Belajar Akuntansi Perusahaan Dagang merupakan usaha yang dicapai atau diperoleh siswa dalam mempelajari pembelajaran akuntansi perusahaan dagang di sekolah selama periode yang telah ditentukan, yang biasanya diwujudkan dalam bentuk angka atau simbol. Prestasi Belajar Akuntansi Perusahaan Dagang merupakan sebagai indikator pemahaman dan penugasan materi yang telah dicapai selama kegiatan pembelajaran.

Berdasarkan observasi dan dokumentasi pada tanggal 4 Maret 2017 dari hasil Ulangan Tengah Semester Genap, di Kelas XI Akuntansi 3 sekitar $75 \%$ dari 24 siswa yang mendapat nilai dibawah KKM 75 (Kriteria Ketuntasan Minimal). Dalam hal ini masih banyak siswa yang memiliki prestasi belajarnya rendah karena belum mencapai KKM yang telah ditentukan oleh pihak SMK YPKK 2 Sleman.

Faktor-faktor yang memengaruhi prestasi belajar siswa dapat dibedakan menjadi dua yaitu faktor internal dan faktor eksternal. Menurut Dalyono (2005: 55-60) faktor yang memengaruhi prestasi belajar secara umum dapat dibedakan menjadi dua, yaitu faktor intern dan faktor ekstern. Faktor intern adalah faktor yang berasal dari dalam diri siswa, seperti kesehatan, intelegensi, perhatian, bakat, minat, motivasi, gaya belajar dan sebagainya. Faktor ekstern adalah faktor yang berasal dari luar diri siswa, seperti lingkungan sekolah, lingkungan keluarga, masyarakat dan sebagainya.

Menurut Slameto (2013: 54), terdapat dua faktor yang memengaruhi belajar yaitu faktor internal dan faktor eksternal. Faktor internal antara lain fisik atau jasmani, kematangan fisik, kelelahan, psikologi berupa bakat, minat, kecerdasan, motivasi dan kemampuan kognitif maupun prestasi. Faktor eksternal meliputi lingkungan alam, lingkungan keluarga (cara orang tua mendidik, relasi antar anggota keluarga, suasana rumah, keadaan ekonomi keluarga, pengertian orang tua, latar belakang kebudayaan), lingkungan sekolah (metode mengajar, media pembelajaran, kurikulum, relasi guru dengan siswa, relasi siswa dengan siswa, disiplin sekolah, waktu sekolah, standar pelajaran di atas ukuran, metode belajar, tugas rumah), dan lingkungan masyarakat (kegiatan siswa dalam masyarakat, teman bergaul, bentuk kehidupan masyarakat).

Faktor internal yang memengaruhi prestasi belajar adalah motivasi belajar. Di dalam kegiatan pengajaran motivasi belajar merupakan suatu masalah yang penting. Keinginan dan dorongan siswa untuk belajar, tentunya berbeda-beda. Ada siswa yang rajin dalam belajar, aktif didalam kelas, dan selalu berusaha mencari sumbersumber belajar guna untuk menambah wawasan yang dimiliki, namun ada pula siswa yang malas-malas belajar, kurang rajin, tidak aktif dikelas, dan bahkan tidak berusaha untuk mencari sumber-sumber belajar yang berguna untuk menunjang wawasan yang dimiliki, karena siswa tersebut hanya mengandalkan guru sebagai pusat informasi ilmu pengetahuannya.

Kesadaran siswa yang kurang dapat memengaruhi belajar siswa, sehingga dapat berdampak pada prestasi siswa itu sendiri. Siswa yang tidak peduli akan prestasi belajarnya cenderung siswa tersebut malas belajar dan tidak memfokuskan dirinya pada masa depan. Dengan motivasi belajar yang tinggi, siswa akan berusaha untuk mengatasi kesulitan-kesulitan belajarnya, sehingga 
apabila kesulitan belajar dapat teratasi maka dimungkinkan dapat berpengaruh terhadap prestasi belajar. Motivasi belajar yang rendah maka prestasi belajar akan rendah, tetapi jika motivasi belajar tinggi maka prestasi belajar akan meningkat. Sehingga motivasi belajar merupakan faktor internal yang dapat memengaruhi prestasi belajar.

Sesuai dengan hasil observasi pada tanggal 4 Maret 2017 di SMK YPKK 2 Sleman khususnya Kelas XI Akuntansi 2, terdapat $50 \%$ dari 24 siswa yang motivasi belajarnya kurang. Hal ini dilihat, pada saat diterangkan oleh guru masih banyak siswa yang tidak memperhatikan guru yang sedang menerangkan dan juga masih ada siswa yang belum mencapai nilai KKM dilihat dari nilai- nilai UTS. Motivasi Belajar siswa yang kurang tersebut diduga menjadi salah satu faktor yang menyebabkan siswa belum mencapai prestasi belajar yang optimal khususnya Prestasi Belajar Mata Pelajaran Akuntansi Perusahaan Dagang.

Faktor eksternal yang memengaruhi prestasi belajar adalah Kompetensi Guru. Guru merupakan salah satu faktor penting yang memengaruhi prestasi belajar siswa. Guru merupakan pendidik profesional yang bertugas untuk mendidik, mengajar, membimbing, mengarahkan, melatih, menilai, dan mengevaluasi siswa (Danim, 2010: 17). Tugas-tugas tersebut tidak akan berjalan dengan baik apabila guru tidak memiliki kompetensi/kemampuan dalam melaksanakannya. Kompetensi yang wajib guru miliki dalam melaksanakan tugastugas tersebut agar terlaksana dengan baik ada empat, yaitu kompetensi pedagogik, kompetensi kepribadian, kompetensi profesional, dan kompetensi sosial.

Dalam hal ini Kompetensi Guru dilihat dari segi persepsi siswa. Persepsi merupakan sebuah proses saat individu mengatur dan menginterpretasikan kesankesan sensori guna memberikan arti bagi lingkungan mereka. Menurut Slameto (2013: 102), persepsi adalah proses yang menyangkut masuknya pesan atau informasi ke dalam otak manusia. Melalu persepsi manusia akan terus-menerus mengadakan hubungan dengan lingkungannya. Perilaku individu seringkali didasarkan pada persepsi mereka tentang kenyataannya, bukan pada kenyataan itu sendiri. Persepsi setiap individu akan muncul persepsi positif dan persepsi negatif, tergantung pada pengamatan dan penilaian individu tersebut. Begitu juga dengan persepsi siswa tentang kompetensi guru, dapat bersifat positif dan negatif, tergantung pada pengamatan dan penilaian siswa mengenai bagaimana guru tersebut bersikap, berkomunikasi, dan mengajar.

Persepsi yang ada pada diri individu akan memengaruhi bagaimana perilaku individu tersebut. Perbedaan pandangan setiap individu pada saat pengamatan akan menghasilkan perbedaan persepsi. Persepsi siswa baik berupa persepsi positif maupun negatif akan memengaruhi perilaku yang tampak. Perilaku positif akan muncul apabila seseorang mempersepsikan secara positif, dan begitu juga perilaku negatif akan muncul ketika seseorang mempersepsikan negatif. Apabila siswa mempersepsikan guru adalah guru yang baik dan menyenangkan, maka siswa akan memperlakukan guru tersebut dengan menghargai dan menghormatinya, dan sebaliknya. Jika persepsi siswa tentang kompetensi guru positif, maka dapat dimungkinkan prestasi belajar siswa akan meningkat, dan sebaliknya, jika persepsi siswa tentang kompetensi guru negatif, maka dapat dimungkinkan prestasi belajar siswa akan menurun, karena dalam hal ini persepsi siswa atau pandangan siswa akan memengaruhi dalam intensitas pencapaian prestasi belajar.

Berdasarkan hasil observasi pada tanggal 21 Maret 2017 di Kelas XI Akuntansi 3 SMK YPKK 2 Sleman dimana $75 \%$ dari 24 siswa prestasi belajar siswa rendah, hal ini diduga disebabkan ada siswa yang memiliki persepsi tentang kompetensi guru yang negatif, jika dilihat dari masih banyak guru yang masuk kelas dengan 
terlambat dan masih banyak guru yang meninggalkan ruang kelas saat jam pelajaran dengan alasan pergi ke ruang guru. Hal tersebut memberikan kesempatan bagi siswa untuk bergurau dengan temantemannya. Persepsi Siswa tentang Kompetensi Guru yang negatif tersebut diduga menjadi salah satu faktor yang menyebabkan prestasi belajar siswa belum secara maksimal terkhusus Prestasi Belajar Akuntansi Perusahaan Dagang.

Faktor eksternal lainnya yang memengaruhi Prestasi Belajar lainnya adalah Lingkungan Keluarga. Menurut Hasbullah (2012: 38) menyatakan bahwa Lingkungan Keluarga adalah lingkungan pendidikan anak yang pertama dan utama karena di dalam keluarga inilah anak pertama dan utama mendapatkan pendidikan dan bimbingan. Dan juga dikatakan sebagai lingkungan yang utama, karena sebagian besar dari kehidupan anak adalah keluarga sehingga pendidikan yang paling banyak diterima oleh anak adalah keluarga. Lingkungan keluarga yang baik akan membentuk dorongan dan semangat bagi setiap individu untuk senantiasa berprestasi, dan sebaliknya lingkungan keluarga yang tidak baik akan membentuk dorongan siswa yang buruk, yaitu biasanya prestasi belajar siswa akan menurun. Berikut Lingkungan Keluarga berkalitan dengan suasana rumah, keadaan ekonomi keluarga, cara orang tua mendidik anak, sikap orang tua kepada anak, saling menghormati antara orang tua dan anak, dan mewujudkan kepercayaan antara orang tua dan anak.

Berdasarkan hasil wawancara pada tanggal 21 Maret 2017 di SMK YPKK 2 Sleman bahwa siswa yang bersekolah di SMK YPKK 2 Sleman merupakan siswa mayoritas ekonomi keluarga dibawah ekonomi menengah bawah, ada $60 \%$ dari 115 siswa yang bersekolah di SMK YPKK 2 Sleman orang tuanya berpenghasilan rendah, sehingga sarana dan prasarana belajar siswa kurang dan selain itu perhatian orang tua terhadap anak juga relatif kurang. Jadi Lingkungan Keluarga tersebut diduga menjadi salah satu faktor eksternal yang menyebabkan siswa belum mencapai Prestasi Belajar yang maksimal terutama Prestasi Belajar Akuntansi Perusahaan Dagang.

Berdasarkan latar belakang masalah di atas, peneliti ingin mengetahui pengaruh Motivasi Belajar, Kompetensi Guru, dan Lingkungan Keluarga terhadap Prestasi Belajar Akuntansi Perusahaan Dagang Siswa Kelas XI Akuntansi SMK YPKK 2 Sleman Tahun Ajaran 2016/2017. Berdasarkan pengamatan, peneliti tertarik untuk meneliti masalah ini ke dalam skripsi dengan judul "Pengaruh Motivasi Belajar, Kompetensi Guru, dan Lingkungan Keluarga terhadap Prestasi Belajar Akuntansi Perusahaan Dagang Siswa Kelas XI Akuntansi SMK YPKK 2 Sleman Tahun Ajaran 2016/2017”.

\section{METODE PENELITIAN}

Penelitian ini menggunakan pendekatan kuantitatif. Penelitian merupakan penelitian expost facto, yaitu penelitian data yang diperoleh adalah data hasil dari peristiwa yang sudah berlangsung. Penelitian ini juga merupakan penelitian kausal komparatif, yaitu penelitian yang bertujuan untuk mengetahui kemungkinan adanya hubungan sebab akibat dengan cara tertentu berdasar atas pengamatan terhadap akibat yang ada, kemudian mencari kembali faktor yang diduga penyebabnya, melalui pengumpulan data.

Populasi dalam penelitian ini adalah seluruh siswa Kelas XI Akuntansi SMK YPKK 2 Sleman Tahun Ajaran 2016/2017 yang terdiri dari 5 kelas dalam jumlah 115 siswa.. Jumlah tersebut terdiri dari kelas XI AK 1 yang berjumlah 22 siswa, XI AK 2 yang berjumlah 24 siswa, XI AK 3 yang berjumlah 24 siswa, XI AK 4 yang berjumlah 22 siswa, dan XI AK 5 yang berjumlah 23 siswa.

Teknik pengumpulan data pada penelitian ini yaitu menggunakan metode angket dan dokumentasi. Metode angket untuk mengumpulkan data mengenai 
Motivasi Belajar, Persepsi Siswa tentang Kompetensi Guru, dan Lingkungan Keluarga. Metode dokumentasi yaitu Prestasi Belajar Akuntansi Perusahaan Dagang berupa rata-rata nilai Ulangan Tengah Semester dan Ulangan Akhir Semester pada semester genap tahun ajaran 2016/2017.

Data pada penelitian ini merupakan data primer, yaitu data yang diperoleh secara langsung. Penelitian ini menggunakan analisis data statistik deskriptif., analisis regresi sederhana dan analisis regresi ganda, serta menghitung sumbangan relatif dan sumbangan efektif. Sebelum menggunakan analisis regresi sedehana dan regresi ganda, data harus lulus uji prasyarat terlebih dahulu. Uji prasyarat analisis yang digunakan yaitu meliput uji linearitas, uji multikolinearitas, dan uji heteroskedastisitas. Analisis data menggunakan bantuan aplikasi statistika. Perhitungan Sumbangan Relatif dimaksudkan untuk mengetahui seberapa besarnya sumbangan secara relatif setiap prediktor terhadap kriteria untuk kepentingan prediksi, sedangkan Sumbangan Efektif bertujuan untuk mengetahui besarnya sumbangan efektif setiap prediktor terhadap kriterium dengan tetap memperhitungkan variabel lain yang tidak diteliti.

\section{HASIL PENELITIAN \\ PEMBAHASAN \\ Analisis Deskriptif}

Data yang diukur melalui dokumentasi dan angket untuk variabel Prestasi Belajar Akuntansi Perusahaan Dagang, Motivasi Belajar, Persepsi Siswa tentang Kompetensi Guru, dan Lingkungan Keluarga mengenai skor maksimal, minimal, mean, dan standar deviasi sebagai berikut:

Tabel 1. Skor Max, Min, Mean, dan Standar Deviasi

\begin{tabular}{|l|c|c|c|c|}
\hline Variabel & Max & Min & Mean & SD \\
\hline $\begin{array}{l}\text { Prestasi } \\
\text { Belajar } \\
\text { Akuntansi }\end{array}$ & 90 & 42 & 71,48 & 13,68 \\
\hline
\end{tabular}

\begin{tabular}{|l|c|c|c|c|}
\hline Variabel & Max & Min & Mean & SD \\
\hline $\begin{array}{l}\text { Perusahaan } \\
\text { Dagang }\end{array}$ & & & & \\
\hline $\begin{array}{l}\text { Motivasi } \\
\text { Belajar }\end{array}$ & 72 & 29 & 47,80 & 9,21 \\
\hline $\begin{array}{l}\text { Persepsi } \\
\text { Siswa } \\
\text { tentang } \\
\begin{array}{l}\text { Kompetensi } \\
\text { Guru }\end{array}\end{array}$ & 60 & 33 & 47,62 & 6,49 \\
\hline $\begin{array}{l}\text { Lingkungan } \\
\text { Keluarga }\end{array}$ & 61 & 30 & 49,66 & 5,531 \\
\hline
\end{tabular}

Berdasarkan hasil tabel diatas dapat diinterpretasikan bahwa untuk variabel Prestasi Belajar Akuntansi Perusahaan Dagang yang diperoleh dari rata-rata nilai Ulangan Tengah Semester dan Ulangan Akhir Semester genap tahun ajaran 2016/2017 dari 115 siswa kelas XI Akuntansi memperoleh skor maksimal 90, skor minimal 42, skor mean sebesar 71,48, dan scok standar deviasi sebesar 13,68. Hal ini menunjukan semakin besar nilai dari standar deviasi, maka semakin besar jarak rata-rata setiap unit data terhadap rata-rata hitung (mean).

Selanjutnya, untuk variabel Motivasi Belajar yang diperoleh dari hasil angket yang disebarkan kepada 115 responden (siswa) memperoleh skor maksimal 72, skor minimal 29, skor mean sebesar 47,80, dan scok standar deviasi sebesar 9,21. Hal ini menunjukan semakin besar nilai dari standar deviasi, maka semakin besar jarak rata-rata setiap unit data terhadap rata-rata hitung (mean).

Selanjutnya, untuk variabel Persepsi Siswa tentang Kompetensi Guru yang diperoleh dari hasil angket yang disebarkan kepada 115 responden (siswa) memperoleh skor maksimal 60, skor minimal 33, skor mean sebesar 47,62, dan scok standar deviasi sebesar 6,49. Hal ini menunjukan semakin besar nilai dari standar deviasi, maka semakin besar jarak rata-rata setiap unit data terhadap rata-rata hitung (mean).

Selanjutnya, untuk variabel terakhir Lingkungan Keluarga yang diperoleh dari 
hasil angket yang disebarkan kepada 115 responden (siswa) memperoleh skor maksimal 61, skor minimal 30, skor mean sebesar 49,66, dan scok standar deviasi sebesar 5,531. Hal ini menunjukan semakin besar nilai dari standar deviasi, maka semakin besar jarak rata-rata setiap unit data terhadap rata-rata hitung (mean).

\section{Uji Hipotesis}

Berikut hasil uji hipotesis yang disajikan dalam tabel dibawah ini:

Tabel 2. Hasil Uji Hipotesis

\begin{tabular}{|l|l|l|l|}
\hline & $\mathbf{X}_{\mathbf{1}}$ & $\mathbf{X}_{\mathbf{2}}$ & $\mathbf{X}_{\mathbf{3}}$ \\
\hline Koefisien & 0,730 & 0,823 & 0,812 \\
\hline Konstanta & 36,574 & 32,272 & 31,160 \\
\hline $\mathrm{R}$ & 0,491 & 0,391 & 0,328 \\
\hline$r^{2}$ & 0,241 & 0,153 & 0,108 \\
\hline $\mathrm{t}_{\text {hitung }}$ & 5,998 & 4,511 & 3,692 \\
\hline $\mathrm{t}_{\text {tabel }}$ & 1,552 & 1,552 & 1,552 \\
\hline Keterangan & Positif & Positif & Positif \\
\hline
\end{tabular}

Sumber: Data Primer yang telah diolah

\section{Uji Hipotesis Pertama}

Hasil penelitian pada variabel Motivasi Belajar $\left(\mathrm{X}_{1}\right)$ menunjukkan koefisien korelasi $\mathrm{r}_{\mathrm{x} 1 \mathrm{y}}$ sebesar 0,491 dan koefisien determinasi $r^{2}{ }_{x 1 y}$ sebesar 0,241, thitung sebesar 5,998. Berdasarkan hasil tersebut menunjukkan Motivasi Belajar berpengaruh positif terhadap Prestasi Belajar Akuntansi Perusahaan Dagang Siswa Kelas XI Akuntansi SMK YPKK 2 Sleman Tahun Ajaran 2016/2017 sebesar 24,1\% dan sisanya $(75,9 \%)$ dipengaruhi oleh faktor lain.

Hasil penelitian ini sejalan dengan teori yang dikemukakan oleh Slameto (2013: 54) mengenai faktor-faktor yang mempengaruhi prestasi belajar. Salah satu faktor yang mempengaruhi Prestasi Belajar Akuntansi Perusahaan Dagang adalah Motivasi Belajar. Hasil penelitian ini selaras dengan penelitian sebelumnya yang dilakukan oleh Nani Listiana (2013) yang berjudul "Pengaruh Motivasi Belajar dan Lingkungan Keluarga terhadap Prestasi Belajar Akuntansi Keuangan Siswa Kelas XI Akuntansi SMK YPKK 3 Sleman Tahun Ajaran 2012/2013", menunjukkan terdapat pengaruh positif dan signifikan Motivasi Belajar terhadap Prestasi Belajar Akuntansi Keuangan Siswa Kelas XI Akuntansi SMK YPKK 3 Sleman Tahun Ajaran 2012/2013yang ditunjukkan dengan nilai $r_{x_{1} y}=0,808, \quad r_{x_{1} y}^{2}=0,652, t_{\text {hitung }}$ $(9,386)>t_{\text {tabel }}(2,021)$ pada taraf signifikansi $5 \%$.

\section{Uji Hipotesis Kedua}

Hasil penelitian pada variabel Persepsi Siswa tentang Kompetensi Guru $\left(\mathrm{X}_{2}\right)$ menunjukkan koefisien korelasi $\mathrm{r}_{\mathrm{x} 2 \mathrm{y}}$ sebesar 0,391 dan koefisien determinasi $r^{2}{ }_{x 2 y}$ sebesar 0,153, thitung sebesar 4,511. Berdasarkan hasil tersebut menunjukkan Persepsi Siswa tentang Kompetensi Guru berpengaruh positif terhadap Prestasi Belajar Akuntansi Perusahaan Dagang Siswa Kelas XI Akuntansi SMK YPKK 2 Sleman Tahun Ajaran 2016/2017 sebesar 15,3\% dan sisanya $(84,7 \%)$ dipengaruhi oleh faktor lain.

Hasil penelitian ini sejalan dengan teori yang dikemukakan oleh Syaodih (2009: 163165) mengenai faktor-faktor yang mempengaruhi prestasi belajar. Salah satu faktor yang mempengaruhi Prestasi Belajar Akuntansi Perusahaan Dagang adalah Persepsi Siswa tentang Kompetensi Guru. Hasil penelitian ini selaras dengan penelitian sebelumnya yang dilakukan oleh Diana Kurnialita (2013) dengan judul "Pengaruh Persepsi Siswa tentang Kompetensi Guru dan Sikap Siswa pada Mata Pelajaran Akuntansi terhadap Prestasi Belajar Akuntansi Siswa Kelas XI IPS SMA Islam 1 Gamping Tahun Ajaran 2012/2013”, menunjukkan terdapat pengaruh positif Persepsi Siswa tentang Kompetensi Guru terhadap Prestasi Belajar Akuntansi Siswa Kelas XI IPS SMA Islam 1 Gamping Tahun Ajaran 2012/2013, yang ditunjukkan dengan nilai $t_{\text {hitung }}(4,022)>t_{\text {tabel }}(2,02)$ dengan koefisien determinasi $r_{x_{1} y}^{2}=0,278$ yang artinya sebesar $27,8 \%$ variabel ini memengaruhi Prestasi Belajar Akuntansi pada taraf signifikansi $5 \%$. 


\section{Uji Hipotesis Ketiga}

Hasil penelitian pada variabel Lingkungan Keluarga $\left(\mathrm{X}_{3}\right)$ menunjukkan koefisien korelasi $\mathrm{r}_{\mathrm{x} 3 \mathrm{y}}$ sebesar 0,328 dan koefisien determinasi $r^{2}{ }_{x 3 y}$ sebesar 0,108 , thitung sebesar 3,692. Berdasarkan hasil tersebut menunjukkan Lingkungan Keluarga berpengaruh positif terhadap Prestasi Belajar Akuntansi Perusahaan Dagang Siswa Kelas XI Akuntansi SMK YPKK 2 Sleman Tahun Ajaran 2016/2017 sebesar 10,8\% dan sisanya $(89,2 \%)$ dipengaruhi oleh faktor lain.

Hasil penelitian ini sejalan dengan teori yang dikemukakan oleh Slameto (2013: 54) mengenai faktor-faktor yang mempengaruhi prestasi belajar. Salah satu faktor yang mempengaruhi Prestasi Belajar Akuntansi Perusahaan Dagang adalah Lingkungan Keluarga. Hasil penelitian ini selaras dengan penelitian sebelumnya yang dilakukan oleh Restu Ragil Pamungkas (2013) dengan judul "Pengaruh Kedisiplinan Belajar dan Lingkungan Keluarga terhadap Prestasi Belajar Akuntansi Siswa Kelas X Program Keahlian Akuntansi SMK Negeri 1 Yogyakarta Tahun Ajaran 2012/2013”, menunjukkan terdapat pengaruh positif dan signifikan Lingkungan Keluarga terhadap Prestasi Belajar Akuntansi Siswa Kelas X Program Keahlian Akuntansi SMK Negeri 1 Yogyakarta Tahun Ajaran 2012/2013, yang ditunjukkan dengan nilai $r_{x_{2} y}=0,791, r^{2}{ }_{x_{2} y}=$ $0,626, t_{\text {hitung }}(10,589)>t_{\text {tabel }}(1,671)$, dengan koefisien beta 0,658 dan pada taraf signifikansi $5 \%$.

Uji Hipotesis Keempat

Tabel 3. Ringkasan Uji Hipotesis Keempat

\begin{tabular}{|l|l|l|l|l|}
\hline Model & $\begin{array}{l}\text { Kons- } \\
\text { tanta }\end{array}$ & $\mathbf{X}_{\mathbf{1}}$ & $\mathbf{X}_{\mathbf{2}}$ & $\mathbf{X}_{\mathbf{3}}$ \\
\hline Koef & $-4,140$ & 0,512 & 0,452 & 0,596 \\
\hline $\mathrm{R}_{\mathrm{y}(1,2,3)}$ & & 0,576 & \\
\hline $\begin{array}{l}\mathrm{R}_{\mathrm{y}(1,2,}^{3} \\
3)\end{array}$ & & 0,332 & \\
\hline $\mathrm{F}_{\text {hitung }}$ & & 18,412 & \\
\hline $\mathrm{F}_{\text {tabel }}$ & & 2,70 & \\
\hline Kete- & & \multicolumn{2}{|l|}{ Positif } & \\
\hline
\end{tabular}

\begin{tabular}{|l|l|l|l|l|}
\hline Model & $\begin{array}{l}\text { Kons- } \\
\text { tanta }\end{array}$ & $\mathbf{X}_{\mathbf{1}}$ & $\mathbf{X}_{\mathbf{2}}$ & $\mathbf{X}_{\mathbf{3}}$ \\
\hline rangan & & \multicolumn{3}{|l|}{} \\
\hline
\end{tabular}

Sumber: Data Primer yang telah diolah

Hasil penelitian ini menunjukkan bahwa Motivasi Belajar, Persepsi Siswa tentang Kompetensi Guru, dan Lingkungan Keluarga secara bersama-sama berpengaruh positif terhadap Prestasi Belajar Akuntansi Perusahaan Dagang. Melalui analisis regresi ganda diperoleh koefiisen regresi ganda $\mathrm{R}_{\mathrm{y}(1,2,3)}$ sebesar 0,576 dan $F_{\text {hitung }}$ sebesar 18,412 sehingga dapat disimpulkan bahwa Motivasi Belajar, Persepsi Siswa tentang Kompetensi Guru, dan Lingkungan Keluarga secara bersama-sama berpengaruh positif terhadap Prestasi Belajar Akuntansi Perusahaan Dagang. Besarnya sumbangan efekif Motivasi Belajar sebesar 10,82\%, Persepsi Siswa tentang Kompetensi Guru sebesar 9,44\%, dan Lingkungan Keluarga sebesar $12,94 \%$ sedangkan $66,80 \%$ berasal dari variabel atau faktor lain yang tidak diteliti dalam penelitian ini.

\section{Sumbangan Relatif dan Sumbangan Efektif}

Tabel 4. Ringkasan Hasil Perhitungan Sumbangan Relatif dan Sumbangan Efektif

\begin{tabular}{|l|c|c|}
\hline \multirow{2}{*}{ Variabel } & \multicolumn{2}{c|}{ Sumbangan } \\
\cline { 2 - 3 } & $\begin{array}{c}\text { Relatif } \\
(\mathbf{\%})\end{array}$ & $\begin{array}{c}\text { Efektif } \\
\mathbf{( \% )}\end{array}$ \\
\hline Motivasi Belajar & $32,59 \%$ & $10,82 \%$ \\
\hline $\begin{array}{l}\text { Persepsi Siswa } \\
\text { tentang Kompetensi } \\
\text { Guru }\end{array}$ & $28,43 \%$ & $9,44 \%$ \\
\hline $\begin{array}{l}\text { Lingkungan } \\
\text { Keluarga }\end{array}$ & $38,98 \%$ & 12,94 \\
\hline Total & $100 \%$ & $33,20 \%$ \\
\hline
\end{tabular}

Berdasarkan hasil perhitungan Sumbangan Relatif dan Sumbagan Efektif, diketahui variabel Motivasi Belajar, Persepsi Siswa tentang Kompetensi Guru, dan Lingkungan Keluarga secara bersama-sama memberikan Sumbangan Efektif sebesar 33,20\% 
sedangkan $66,80 \%$ diberikan oleh variabelvariabel lain yang tidak diteliti dan dibahas dalam penelitian ini.

\section{SIMPULAN DAN SARAN Simpulan}

Berdasarkan hasil pembahasan diatas dapat ditarik kesimpulan bawa Motivasi Belajar berpengaruh positif terhadap Prestasi Belajar Akuntansi Perusahaan Dagang Siswa Kelas XI Akuntansi SMK YPKK 2 Sleman Tahun Ajaran 2016/2017, dengan $r_{x 1 y}$ sebesar 0,491, $r^{2}$ x1y sebesar 0,241 dengan taraf signifikansi $5 \%$.

Selanjutnya, Persepsi Siswa tentang Kompetensi Guru berpengaruh positif terhadap Prestasi Belajar Akuntansi Perusahaan Dagang Siswa Kelas XI Akuntansi SMK YPKK 2 Sleman Tahun Ajaran 2016/2017, dengan $r_{x 2 y}$ sebesar $0,391, r^{2} \times 2 y$ sebesar 0,153 dengan taraf signifikansi $5 \%$.

Selanjutnya, Lingkungan Keluarga berpengaruh positif terhadap Prestasi Belajar Akuntansi Perusahaan Dagang Siswa Kelas XI Akuntansi SMK YPKK 2 Sleman Tahun Ajaran 2016/2017, dengan $r_{x 3 y}$ sebesar $0,328, r^{2}{ }_{x 3 y}$ sebesar 0,108 dengan taraf signifikansi 5\%.

Selanjutnya, Motivasi Belajar, Persepsi Siswa tentang Kompetensi Guru, dan Lingkungan Keluarga secara bersama-sama berpengaruh positif terhadap Prestasi Belajar Akuntansi Perusahaan Dagang Siswa Kelas XI Akuntansi SMK YPKK 2 Sleman Tahun Ajaran 2016/2017, dengan $R_{y(1,2,3)}$ sebesar $0,576, \mathrm{R}_{\mathrm{y}(1,2,3)}^{2}$ sebesar 0,332, dan $\mathrm{F}_{\text {hitung }}$ sebesar 18,412 .

\section{Saran}

Motivasi Belajar butir pernyataan nomor 5 (Saya sudah mempelajari materi pelajaran akuntansi terlebih dahulu di rumah, sebelum guru menyampaikan materi tersebut di kelas) memiliki jumlah skor jawaban paling rendah, maka dalam hal ini sebaiknya guru mengarahkan siswa untuk mempelajari materi dirumah sebelum guru menjelaskan, agar saat dijelaskan siswa sudah memahami dan sudah siap untuk menerima materi tersebut. Sehingga hal tersebut dapat membantu guru dalam meningkatkan prestasi belajar siswa.

Persepsi Siswa tentang Kompetensi Guru butir pernyataan nomor 11 (Guru mengaitkan materi pelajaran dengan situasi sehari-hari) memiliki jumlah skor jawaban paling rendah, maka hal ini sebaiknya guru dalam menyampaikan materi yang akan dijelaskan kepada siswa harus mengaitkan dengan kehidupan sehari-hari, agar siswasiswa dapat menelaah dan dapat memahami dengan jelas bahwa apa yang telah dipelajari ternyata ada dalam kehidupan sehari-hari yang mereka jalani. Siswa lebih mudah memahami materi dengan melihat kondisi langsung lapangan, dibandingkan hanya teori dalam buku saja. Karena teori harus dibuktikan dikehidupan nyata, agar mudah dipahami dan dicerna oleh siswa-siswa.

Lingkungan Keluarga butir pernyataan nomor 11 (Orang tua saya mendidik saya dengan sikap yang keras) memiliki jumlah skor jawaban paling rendah, maka hal ini sebaiknya orang tua dalam mendidik anak jangan terlalu keras, karena tidak semua anak bisa dididik dengan keras. Dalam mendidik orang tua harus menyesuaikan kondisi anak tersebut, apakah bisa didik keras atau tidak. Sesungguhnya mendidik seorang anak tidak harus dengan keras.

\section{DAFTAR PUSTAKA}

Arikunto, S. (2013). Dasar-dasar Evaluasi Pendidikan. Jakarta: Rineka Cipta.

Dalyono, M. (2005). Psikologi Pendidikan. Jakarta: Rineka Cipta.

Danim, Sudarwan. (2010). Profesionalisasi dan Etika Profesi Guru. Bandung: Alfabeta.

Hasbullah. (2012). Dasar-dasar Ilmu Pendidikan. Jakarta: PT Rajagrafindo Persada.

Kurnialita, Diana. (2013). "Pengaruh Persepsi Siswa tentang Kompetensi 
Guru dan Sikap Siswa pada Mata Pelajaran Akuntansi terhadap Prestasi Belajar Akuntansi Siswa Kelas XI IPS SMA Islam 1 Gamping Tahun Ajaran 2012/2013”. Skripsi. Universitas Negeri Yogyakarta.

Liatiana, Nani. (2013). "Pengaruh Motivasi Belajar dan Lingkungan Keluarga Terhadap Prestasi Belajar Akuntansi Keuangan Siswa Kelas XI Akuntansi SMK YPKK 3 Sleman Tahun Ajaran Slameto. (2013). Belajar dan Faktor-faktor yang Mempengaruhinya. Jakarta: Rineka Cipta.

Sukmadinata, Nana S. (2009). Landasan Psikologi Proses Pendidikan. Bandung: PT Remaja Rosdakarya.

UU RI No. 14 tahun 2005: Guru dan Dosen. Diambil dari (http://sindikker.dikti.go.id/dok/UU/U UNo142005(Guru\%20\&\%20Dosen).p df), pada tanggal 26 Maret 2017.
2012/2013". Skripsi. Universitas Negeri Yogyakarta.

Ragil P, Restu. (2013). "Pengaruh Kedisiplinan Belajar dan Lingkungan Keluarga terhadap Prestasi Belajar Akuntansi Siswa Kelas X Program Keahlian Akuntansi SMK Negeri 1 Yogyakarta Tahun Ajaran 2012/2013". Skripsi. Universitas Negeri Yogyakarta. 